\title{
Tubastatin A, an inhibitor of HDAC6, enhances temozolomide-induced apoptosis and reverses the malignant phenotype of glioblastoma cells
}

\author{
ALEJANDRO URDICIAIN $^{1 *}$, ELENA ERAUSQUIN $^{1 *}$, BÁRBARA MELÉNDEZ $^{2}$, \\ JUAN A. REY ${ }^{3}$, MIGUEL A. IDOATE $^{4}$ and JAVIER S. CASTRESANA ${ }^{1}$ \\ ${ }^{1}$ Department of Biochemistry and Genetics, University of Navarra School of Sciences, \\ 31008 Pamplona; ${ }^{2}$ Molecular Pathology Research Unit, Virgen de la Salud Hospital, \\ 45071 Toledo; ${ }^{3}$ IdiPaz Research Unit, La Paz University Hospital, 28046 Madrid; \\ ${ }^{4}$ Department of Pathology, University of Navarra Clinic, 31008 Pamplona, Spain
}

Received October 24, 2018; Accepted January 24, 2019

DOI: 10.3892/ijo.2019.4739

\begin{abstract}
Glioblastoma or grade IV astrocytoma is the most common and lethal form of glioma. Current glioblastoma treatment strategies use surgery followed by chemotherapy with temozolomide. Despite this, numerous glioblastoma cases develop resistance to temozolomide treatments, resulting in a poor prognosis for the patients. Novel approaches are being investigated, including the inhibition of histone deacetylase 6 (HDAC6), an enzyme that deacetylates $\alpha$-tubulin, and whose overexpression in glioblastoma is associated with the loss of primary cilia. The aim of the present study was to treat glioblastoma cells with a selective HDAC6 inhibitor, tubastatin A, to determine if the malignant phenotype may be reverted. The results demonstrated a notable increase in acetylated $\alpha$-tubulin levels in treated cells, which associated with downregulation of the sonic hedgehog pathway, and may hypothetically promote ciliogenesis in those cells. Treatment with tubastatin A also reduced glioblastoma clonogenicity and migration capacities, and accelerated temozolomide-induced apoptosis. Finally, HDAC6 inhibition decreased the expression of mesenchymal markers, contributing to reverse epithelial-mesenchymal transition in glioblastoma cells.
\end{abstract}

Correspondence to: Professor Javier S. Castresana, Department of Biochemistry and Genetics, University of Navarra School of Sciences, Irunlarrea 1, 31008 Pamplona, Spain

E-mail: jscastresana@unav.es

*Contributed equally

Abbreviations: EMT, epithelial-mesenchymal transition; HDAC6, histone deacetylase 6; MGMT, $\mathrm{O}^{6}$-methylguanine-DNA methyltransferase

Key words: HDAC6, tubastatin A, temozolomide, glioblastoma, sonic hedgehog

\section{Introduction}

Glioblastoma or grade IV astrocytoma is the most common form of glioma in adults, accounting for $60-70 \%$ of all gliomas, as well as the most aggressive brain tumor (1). Glioblastoma treatment currently involves extensive surgical resection followed by external-beam radiation and concomitant temozolomide chemotherapy (2). Temozolomide is an alkylating agent that forms $\mathrm{O}^{6}$-methylguanine in DNA, which miss-pairs with thymine during the next DNA replication cycle (3). These critical lesions progress to lethal DNA cross-links, which inhibit cell replication and result in cell death (4,5). Despite this therapeutic effort, numerous glioblastoma cases develop resistance to chemotherapy, which results in a poor prognosis for the patients, who only have a median survival time of 14.6 months after diagnosis (5). $\mathrm{O}^{6}$-methylguanine-DNA methyltransferase (MGMT), a DNA repair enzyme, is responsible for inducing temozolomide resistance (6,7). MGMT removes alkyl groups from the $\mathrm{O}^{6}$ position of guanine (8). MGMT promoter methylation has been observed in $40-57 \%$ of glioblastoma cases; additionally, when this occurs, MGMT is not transcribed and cannot repair DNA damage caused by temozolomide. Left unrepaired, these chemotherapy-induced lesions trigger cytotoxicity and apoptosis, thus resulting in more efficient treatment (9). For this reason, MGMT promoter methylation status can be considered as an important predictive factor for good therapeutic response and hence survival of patients with glioblastoma.

Histone deacetylases (HDACs) are primarily involved in the deacetylation of histones, but a number of HDACs, including HDAC6, can also affect the function of cytoplasmic non-histone proteins, becoming key regulators of cancer signaling pathways $(10,11)$. A major substrate of HDAC6 is acetylated $\alpha$-tubulin (10), the structural protein of the microtubules that form a whole variety of cellular structures, including the primary cilium (12). HDAC6 overexpression, which has been demonstrated to occur in numerous glioblastoma cases (13), rapidly deacetylates $\alpha$-tubulin, resulting in depolymerization of microtubules and disruption of the primary cilium (12). 
Aberrant ciliogenesis is a common defect, as determined in five glioblastoma cells lines, which may contribute to the phenotype of these malignant cells $(14,15)$. Cilia have been implicated in numerous signaling pathways important in embryonic development and disease, including the Hedgehog (Hh) $(16,17)$, Wnt (18) and platelet-derived growth factor (17) pathways.

In vertebrate cells, the sonic Hh pathway requires primary cilia (19). A probable mechanistic function of the cilium is to regulate the Hh pathway by increasing the local concentration and bringing pathway components together for key protein-protein interactions required for regulation, including the presence of Smo in the primary cilium being required for the genesis of Gli activated forms, while the absence of Smo will generate Gli repressor forms (20-22). Among Gli targets, a number of proteins, including cyclins D1 and D2, insulin like growth factor binding protein-6, B-cell lymphoma-2, GLI1 and Myc-N, can be observed (20). Furthermore, GLI1 has been associated with increased expression of MGMT (23). Cyclopamine, an effective Smo antagonist, competitively binds the Smo receptor and subsequently inhibits the Hh pathway (23). However, those cancer cells that lack cilia would not be responsive to this type of Smo inhibitors, and instead would be required to be treated with downstream inhibitors, such as the Gli antagonists (21). Based on this, only ciliated cells, or cells that had been previously exposed to cilia formation promoters, such as tubastatin, would respond to cyclopamine.

Epithelial-mesenchymal transition (EMT) is the biological process by which cells lose their epithelial characteristics and acquire a mesenchymal cell phenotype, which includes enhanced migratory capacity, invasiveness, elevated resistance to apoptosis and increased production of extracellular matrix components $(22,24-26)$ (Table I). EMT is considered a promoter of metastasis, due to the transformations through which cells acquire motility (27). EMT is induced by growth factors, including transforming growth factor (TGF)-1, that decreases expression of E-cadherin $(25,28,29)$, but at the same time increases expression of HDAC6 (30). Following this reasoning, inhibition of HDAC6 by a selective inhibitor, such as tubastatin A, would reduce TGF-induced downregulation of E-cadherin, and therefore EMT.

For the present study, two glioblastoma cell lines, LN405 and $\mathrm{T} 98 \mathrm{G}$, were treated with a selective HDAC6 inhibitor, tubastatin A, to determine whether this treatment modulates the sonic Hh pathway, reduces tumor cell clonogenicity and migration capacities, counteracts EMT and sensitizes glioblastoma cells to chemotherapy with temozolomide.

\section{Materials and methods}

Glioblastoma cell lines. The present study was performed using T98G and LN405 glioblastoma cell lines in all experiments conducted. T98G cells were obtained from the European Collection of Cell Cultures (Salisbury, UK) and are derived from a glioblastoma multiform tumor from a 61-year-old Caucasian male. LN405 cells were purchased from The Leibniz-Institute DSMZ (German Collection of Microorganisms and Cell Cultures, Braunschweig, Germany) and correspond to glioblastoma cells established from an astrocytoma tumor (grade IV) of a 62-year-old female in 1986. The cell lines were cultured in Gibco RPMI-1640 GlutaMAX ${ }^{\mathrm{TM}}$
Table I. Common epithelial and mesenchymal markers for epithelial-mesenchymal transition evaluation.

\begin{tabular}{lll}
$\begin{array}{l}\text { Types of proteins } \\
\text { or RNA }\end{array}$ & \multicolumn{1}{c}{$\begin{array}{c}\text { Epithelial } \\
\text { markers }\end{array}$} & $\begin{array}{c}\text { Mesenchymal } \\
\text { markers }\end{array}$ \\
\hline Cell-surface proteins & E-cadherin & $\begin{array}{l}\text { N-cadherin } \\
\text { OB-cadherin } \\
\end{array}$ \\
& & $\begin{array}{l}\alpha \text { ZO-1 } \\
\text { Syndecan-1 }\end{array}$ \\
Cytoskeletal markers & Cytokeratin & Vimentin \\
& & $\beta$-catenin \\
ECM proteins & $\alpha 1$ (IV) collagen & $\alpha 1$ (I) collagen \\
& Laminin 1 & $\alpha 1$ (III) collagen \\
& & Fibronectin \\
& & Laminin 5 \\
Transcriptional factors & & Snail \\
& & Slug \\
& & ZEB1 \\
& & Twist \\
miRNAs & & miR-10b \\
& & miR-21 \\
& miR-200 family &
\end{tabular}

ZO-1,Zonula occludens-1; Slug, Snail family transcription repressor 2; ZEB1, zinc finger E-box binding homeobox 1; ECM, extracellular matrix; miRNAs, microRNAs.

medium, supplemented with $10 \%$ fetal bovine serum (FBS) and $1 \%$ penicillin/streptomycin (all from Thermo Fisher Scientific, Inc., Waltham, MA, USA). These cells were grown as a monolayer in $75 \mathrm{~cm}^{2}$ flasks and maintained in an incubator at $37^{\circ} \mathrm{C}$ in an atmosphere containing $5 \% \mathrm{CO}_{2}$.

MTT (thiazolyl blue tetrazolium bromide) assay. The MTT tetrazolium reduction assay is frequently used to estimate the number of viable eukaryotic cells and calculate the median lethal dose (LD50) for screening collections of compounds to determine if the test molecules exhibit direct cytotoxic effects that eventually result in cell death. Viable cells with active mitochondrial metabolism convert MTT substrate into a purple colored formazan product with an absorbance maximum $\sim 570 \mathrm{~nm}$. When cells die, they lose the ability to convert MTT into formazan, thus color formation serves as a useful and convenient marker (presumably directly proportional) of only the viable cells. This reaction generally involves NADH as a cofactor (31). This method requires the incubation of the MTT substrate at a final concentration of $0.5 \mathrm{mg} / \mathrm{ml}$ for $1.5 \mathrm{~h}$ at $37^{\circ} \mathrm{C}$, with a population of viable cells that have previously been cultured in 96-well plates until reaching a confluence of 5,000 cells/well, and treated with each tested drug: For cyclopamine and tubastatin A the concentrations used were $0,5,10,15,20,25,30,35,40,45$ and $50 \mu \mathrm{M}$; while for temozolomide the concentrations used were 0 , $50,100,150,200,250,300,350,400,450,500,550,600,650,700$, $750,800,850,900,950$ and $1000 \mu \mathrm{M}$. After $1.5 \mathrm{~h}$, MTT substrate was discarded to avoid cytotoxicity due to the reagent [as the conversion to formazan by cells in culture is time-dependent (31)] and dimethyl sulfoxide (DMSO) was added to each sample. The 
Table II. Mutational status of PTEN and p53 in the glioblastoma cell lines, and concentrations of cyclopamine, tubastatin A and temozolomide.

\begin{tabular}{lllccc}
\hline Cell line & PTEN & p53 & Cyclopamine & Tubastatin A & Temozolomide \\
\hline LN405 & MUT & MUT & $27.5 \mu \mathrm{M}$ & $32.5 \mu \mathrm{M}$ & $400 \mu \mathrm{M}$ \\
T98G & WT & MUT & $20 \mu \mathrm{M}$ & $30 \mu \mathrm{M}$ & $400 \mu \mathrm{M}$ \\
\hline
\end{tabular}

MUT, mutated; WT, wild-type; PTEN, phosphatase and tensin homolog.

resulting absorbance was monitored at $550 \mathrm{~nm}$ wavelength using the Multiskan EX reading spectrophotometer. Following MTT tests, cyclopamine, tubastatin A and temozolomide were used in LN405 cells at final concentrations of 27.5, 32.5 and $400 \mu \mathrm{M}$, respectively. In T98G cells, cyclopamine and tubastatin A were used at final concentrations of 20 and $30 \mu \mathrm{M}$, respectively. Treatments were conducted at $37^{\circ} \mathrm{C}$ for $72 \mathrm{~h}$. Temozolomide LD50 could not be achieved in T98G cells; therefore, a final concentration of $400 \mu \mathrm{M}$ was selected (Table II).

$2 D$ colony formation assay. The aim of the 2D colony formation assay was to investigate the attachment-dependent growth of cells when exposed to different drugs. Cells were treated at $37^{\circ} \mathrm{C}$ for $72 \mathrm{~h}$ as follows: LN405 with $27.5 \mu \mathrm{M}$ cyclopamine, $32.5 \mu \mathrm{M}$ tubastatin A and $400 \mu \mathrm{M}$ temozolomide; and T98G with $20 \mu \mathrm{M}$ cyclopamine, $30 \mu \mathrm{M}$ tubastatin A and $400 \mu \mathrm{M}$ temozolomide. Concentrations and durations for the combination of cyclopamine and tubastatin $\mathrm{A}$, and the combination of temozolomide and tubastatin A, were as for the single treatments. Additionally, $1 \%$ DMSO was used as a vehicle control. Subsequently, 300 cells/well were cultured in six-well agarose plates, with 3 wells/condition at $37^{\circ} \mathrm{C}$ in a $5 \% \mathrm{CO}_{2}$ incubator for 10 days. Subsequently, cells were fixed with $4 \%$ paraformaldehyde for $40 \mathrm{~min}$ at room temperature and stained with crystal violet (Sigma-Aldrich; Merck KGaA, Darmstadt, Germany) for $15 \mathrm{~min}$ at room temperature. Resulting colonies were counted using a Suntex 560 Colony Counter (Gemini, Apeldoorn, The Netherlands).

3D colony formation assayin softagar. The 3D colony formation assay was conducted to investigate the attachment-independent growth capacity of the cell lines when exposed to different drugs. Cells were treated at $37^{\circ} \mathrm{C}$ for $72 \mathrm{~h}$ as follows: LN405 with $27.5 \mu \mathrm{M}$ cyclopamine, $32.5 \mu \mathrm{M}$ tubastatin $\mathrm{A}$ and $400 \mu \mathrm{M}$ temozolomide; and T98G with $20 \mu \mathrm{M}$ cyclopamine, $30 \mu \mathrm{M}$ tubastatin A and $400 \mu \mathrm{M}$ temozolomide. Concentrations and durations for the combination of cyclopamine and tubastatin A, and the combination of temozolomide and tubastatin $\mathrm{A}$, were as for the single treatments. Additionally, $1 \%$ DMSO was used as a vehicle control. Subsequently, 10,000 cells/well were cultured in six-well agarose plates, with 3 wells/condition at $37^{\circ} \mathrm{C}$ in a $5 \% \mathrm{CO}_{2}$ incubator for 2 weeks. Previously, $2 \mathrm{ml}$ agarose $0.5 \%$ (cat. no. 8016; Pronadisa, Laboratorios Conda, Torrejón de Ardoz, Madrid, Spain) with Dulbecco's modified Eagle's medium (DMEM; Sigma-Aldrich; Merck KGaA) were added to the wells. When this first layer had gelled, 10,000 cells contained in $2 \mathrm{ml}$ agarose $0.2 \%$ and $1 \mathrm{X}$ DMEM were added onto it. Once the top layer containing the cells had gelled,
$2 \mathrm{ml}$ fresh medium (Gibco RPMI-1640 GlutaMAX ${ }^{\mathrm{TM}}$ medium supplemented with $10 \% \mathrm{FBS}$ and $1 \%$ penicillin/streptomycin) were added, incubated at $37^{\circ} \mathrm{C}$ in a $5 \% \mathrm{CO}_{2}$ incubator and changed every 3 days. After 2 weeks, the medium was discarded, and the colonies were stained with crystal violet for $5 \mathrm{~min}$ at room temperature. Samples were washed 5 times with water to improve visualization of the colonies, and then an image of each well was captured and analyzed with the colony-forming unit free software OpenCFU (32).

Wound healing assay. This assay was performed to investigate the migration capacity of the cells following treatment. Cells were treated at $37^{\circ} \mathrm{C}$ for $72 \mathrm{~h}$ as follows: LN405 with $27.5 \mu \mathrm{M}$ cyclopamine, $32.5 \mu \mathrm{M}$ tubastatin A and $400 \mu \mathrm{M}$ temozolomide; and T98G with $20 \mu \mathrm{M}$ cyclopamine, $30 \mu \mathrm{M}$ tubastatin $\mathrm{A}$ and $400 \mu \mathrm{M}$ temozolomide. Concentrations and durations for the combination of cyclopamine and tubastatin A, and the combination of temozolomide and tubastatin A, were as for the single treatments. Additionally, $1 \%$ DMSO was used as a vehicle control. Subsequently, cells were cultured at $37^{\circ} \mathrm{C}$ in a $5 \% \mathrm{CO}_{2}$ incubator in 24-well plates, at a concentration of 250,000 cells/well. After $24 \mathrm{~h}$, a scratch was produced in the middle of the well and medium was changed to one containing $2.5 \% \mathrm{FBS}$ in order to avoid proliferation and apoptosis of the cells. Images were captured at 0, 8, 24,32 and $48 \mathrm{~h}$ after scratching with a Nikon SMZ18 light microscope, at x10 magnification.

Cell death detection ELISA ${ }^{\text {PLUS }}$. The Cell Death Detection ELISA $^{\text {PLUS }}$ (Roche Diagnostics GmbH, Mannheim, Germany; cat. no. 11544675001) was used in order to investigate the effect of different drugs on apoptosis. This assay is based on a quantitative sandwich-enzyme-immunoassay-principle using mouse monoclonal antibodies directed against DNA and histones. This allows the specific determination of mono- and oligonucleosomes in the cytoplasmic fraction of cell lysates. For this experiment, cells were cultured at $37^{\circ} \mathrm{C}$ in a $5 \% \mathrm{CO}_{2}$ incubator in 96-well plates at a concentration of 5,000 cells/well, with 4 wells/condition. After $24 \mathrm{~h}$, treatments were added to each corresponding well, and cells were treated at $37^{\circ} \mathrm{C}$ for $72 \mathrm{~h}$ as follows: LN405 with $27.5 \mu \mathrm{M}$ cyclopamine, $32.5 \mu \mathrm{M}$ tubastatin $\mathrm{A}$ and $400 \mu \mathrm{M}$ temozolomide; and T98G with $20 \mu \mathrm{M}$ cyclopamine, $30 \mu \mathrm{M}$ tubastatin $\mathrm{A}$ and $400 \mu \mathrm{M}$ temozolomide. Concentrations and durations for the combination of cyclopamine and tubastatin A, and the combination of temozolomide and tubastatin A, were as for the single treatments. Additionally, $1 \%$ DMSO was used as a vehicle control. Apoptosis was measured at 24, 48 and $72 \mathrm{~h}$ following the manufacturer's protocols. 
Table III. Sequences and melting temperatures of primers used for reverse transcription-quantitative polymerase chain reaction.

\begin{tabular}{llll}
\hline Gene & \multicolumn{1}{c}{ Forward primer $\left(5^{\prime}-3^{\prime}\right)$} & \multicolumn{1}{c}{ Reverse primer $\left(5^{\prime}-3^{\prime}\right)$} & Temperature $\left({ }^{\circ} \mathrm{C}\right)$ \\
\hline $18 \mathrm{~S}$ & GTAACCCGTTGAACCCATT & CCATCCAATCGGTAGTAGCG & 63 \\
Gli1 & AAGCGTGAGCCTGAATCTGT & CAGCATGTACTGGGCTTTGA & 61 \\
PTCH1 & AGTGTCGCACAGAACTCCACT & GCATAGGCGAGCATGAGTAAG & 63 \\
Snail & GGTTCTTCTGCGCTACTGCT & TAGGGCTGCTGGAAGGTAAA & 63 \\
Slug & CATTTCAACGCCTCCAAAA & GGAATGGAGCAGCGGTAGT & 63 \\
\hline
\end{tabular}

PTCH1, Patched 1; Slug, Snail family transcription repressor 2.

Caspase-Glo $3 / 7$ assay. The Caspase-Glo ${ }^{\circledR} 3 / 7$ assay (Promega Corporation, Madison, WI, USA) is a homogeneous, luminescent assay that measures caspase- 3 and caspase-7 activities. The kit provides a luminogenic caspase-3/7 substrate, which contains the tetrapeptide sequence DEVD. The addition of this reagent results in cell lysis, followed by caspase cleavage of the substrate and generation of a glow-type luminescent signal produced by luciferase. Luminescence is proportional to the amount of caspase activity present. Cells were cultured at $37^{\circ} \mathrm{C}$ for $72 \mathrm{~h}$ in Gibco RPMI-1640 GlutaMAX $^{\mathrm{TM}}$ medium, supplemented with $10 \%$ FBS and $1 \%$ penicillin/streptomycin, in $96-$ well plates at a concentration of 5,000 cells/well, with 4 wells/condition. After $24 \mathrm{~h}$, cells were added to each corresponding well, that were treated at $37^{\circ} \mathrm{C}$ for $72 \mathrm{~h}$ as follows: LN405 with $27.5 \mu \mathrm{M}$ cyclopamine, $32.5 \mu \mathrm{M}$ tubastatin $\mathrm{A}$ and $400 \mu \mathrm{M}$ temozolomide; and T98G with $20 \mu \mathrm{M}$ cyclopamine, $30 \mu \mathrm{M}$ tubastatin $\mathrm{A}$ and $400 \mu \mathrm{M}$ temozolomide. Concentrations and durations for the combination of cyclopamine and tubastatin A, and the combination of temozolomide and tubastatin A, were as for the single treatments. Additionally, $1 \%$ DMSO was used as a vehicle control. Caspase-3/7 activation was measured at 24, 48 and $72 \mathrm{~h}$, following the manufacturer's protocols.

RNA extraction. Total RNA extraction from $72 \mathrm{~h}$ treated cells was conducted following the TRIzol ${ }^{\circledR}$ reagent (Invitrogen; Thermo Fisher Scientific,Inc.) protocol, which allows sequential precipitation of RNA, DNA and proteins from a single sample. Cells were treated at $37^{\circ} \mathrm{C}$ for $72 \mathrm{~h}$ as follows: LN405 with $27.5 \mu \mathrm{M}$ cyclopamine, $32.5 \mu \mathrm{M}$ tubastatin $\mathrm{A}$ and $400 \mu \mathrm{M}$ temozolomide; and $\mathrm{T} 98 \mathrm{G}$ with $20 \mu \mathrm{M}$ cyclopamine, $30 \mu \mathrm{M}$ tubastatin $\mathrm{A}$ and $400 \mu \mathrm{M}$ temozolomide. Concentrations and durations for the combination of cyclopamine and tubastatin A, and the combination of temozolomide and tubastatin A, were as for the single treatments. Additionally, $1 \%$ DMSO was used as a vehicle control. Following homogenization of the samples with TRIzol reagent, chloroform was added to separate (after 15 min centrifugation at 12,000 x g and $4^{\circ} \mathrm{C}$ ) into a clear upper aqueous layer containing RNA, an interphase and a red lower organic layer containing DNA and proteins. RNA precipitation was then achieved by the addition of isopropanol and centrifugation for $30 \mathrm{~min}$ at $12,000 \mathrm{x} \mathrm{g}$ and $4^{\circ} \mathrm{C}$. Subsequently, isopropanol was removed, and $1 \mathrm{ml}$ $75 \%$ ethanol in diethyl pyrocarbonate (DEPC) water was added, vortexed and centrifuged for $5 \mathrm{~min}$ at 7,500 $\mathrm{x}$ and $4^{\circ} \mathrm{C}$. The process was repeated once more. Subsequently, ethanol was removed, the RNA pellet was left to dry, and resuspended in $15 \mu \mathrm{l}$ DEPC water, to finally be stored at $-80^{\circ} \mathrm{C}$ for use in downstream applications. Total RNA quantification in each sample was measured using NanoDrop ${ }^{\mathrm{TM}}$ Microvolume Spectrophotometer (Thermo Fisher Scientific, Inc.).

Reverse transcription-quantitative polymerase chain reaction $(R T-q P C R)$. For reverse transcription, $2 \mu \mathrm{g}$ RNA were mixed with $1 \mu \mathrm{l}$ random primers $(250 \mathrm{ng} / \mu \mathrm{l})$ and $1 \mu \mathrm{l} \mathrm{dNTPs}$ mix $(10 \mu \mathrm{M})$ in a final volume of $12 \mu \mathrm{l}$ water. Random primers (cat. no. 48190011) were purchased from Thermo Fisher Scientific, Inc.. This mixture was incubated for $5 \mathrm{~min}$ at $65^{\circ} \mathrm{C}$. Subsequently, $4 \mu \mathrm{l}$ first strand buffer and $2 \mu \mathrm{l}$ DTT were added, and this was incubated for $2 \mathrm{~min}$ at $25^{\circ} \mathrm{C}$. Following this, $1 \mu \mathrm{l}$ SuperScript II Reverse Transcriptase (Invitrogen; Thermo Fisher Scientific, Inc.) was added for the synthesis of cDNA and this final mixture was incubated for $10 \mathrm{~min}$ at $25^{\circ} \mathrm{C}$, $50 \mathrm{~min}$ at $42^{\circ} \mathrm{C}$ and finally $15 \mathrm{~min}$ at $72^{\circ} \mathrm{C}$. Furthermore, $80 \mu \mathrm{l}$ water were added and the cDNA was stored at $-20^{\circ} \mathrm{C}$.

RT-qPCR was used to analyze the expression of genes associated with the sonic Hh pathway and EMT in six different conditions (DMSO as control, tubastatin A, cyclopamine, temozolomide, tubastatin A plus temozolomide and tubastatin A plus cyclopamine). Cells were treated at $37^{\circ} \mathrm{C}$ for $72 \mathrm{~h}$ as follows: LN405 with $27.5 \mu \mathrm{M}$ cyclopamine, $32.5 \mu \mathrm{M}$ tubastatin A and $400 \mu \mathrm{M}$ temozolomide; and T98G with $20 \mu \mathrm{M}$ cyclopamine, $30 \mu \mathrm{M}$ tubastatin $\mathrm{A}$ and $400 \mu \mathrm{M}$ temozolomide. Concentrations and durations for the combination of cyclopamine and tubastatin A, and the combination of temozolomide and tubastatin A, were as for the single treatments. Additionally, $1 \%$ DMSO was used as a vehicle control. Amplification reactions were conducted in an IQ5 multicolor real-time PCR detection system (Bio-Rad Laboratories, Inc., Hercules, CA, USA). Subsequently, $1 \mu \mathrm{l}$ of each sample cDNA was used in a total volume of $20 \mu \mathrm{l} /$ well, with a reaction mix containing $10 \mu \mathrm{l}$ $\mathrm{IQ}^{\mathrm{TM}} \mathrm{SYBR}^{\circledR}$ Green supermix (Bio-Rad Laboratories, Inc.). An initial denaturation step at $95^{\circ} \mathrm{C}$ for $30 \mathrm{sec}$ was followed by 40 cycles of amplification alternating between $95^{\circ} \mathrm{C}$ for $10 \mathrm{sec}$, the corresponding annealing temperature for each gene for $30 \mathrm{sec}$ and $72^{\circ} \mathrm{C}$ for another $30 \mathrm{sec}$ (Table III). Each sample was assayed in triplicate. Forward and reverse primers were designed using Primer3Plus (http://www.bioinformatics. nl/cgi-bin/primer3plus/primer3plus.cgi). Sequences and melting temperatures of each primer pair are depicted in Table III. Ribosomal 18S gene was used as a housekeeping reference gene for the relative quantification of cDNA amount, 
A
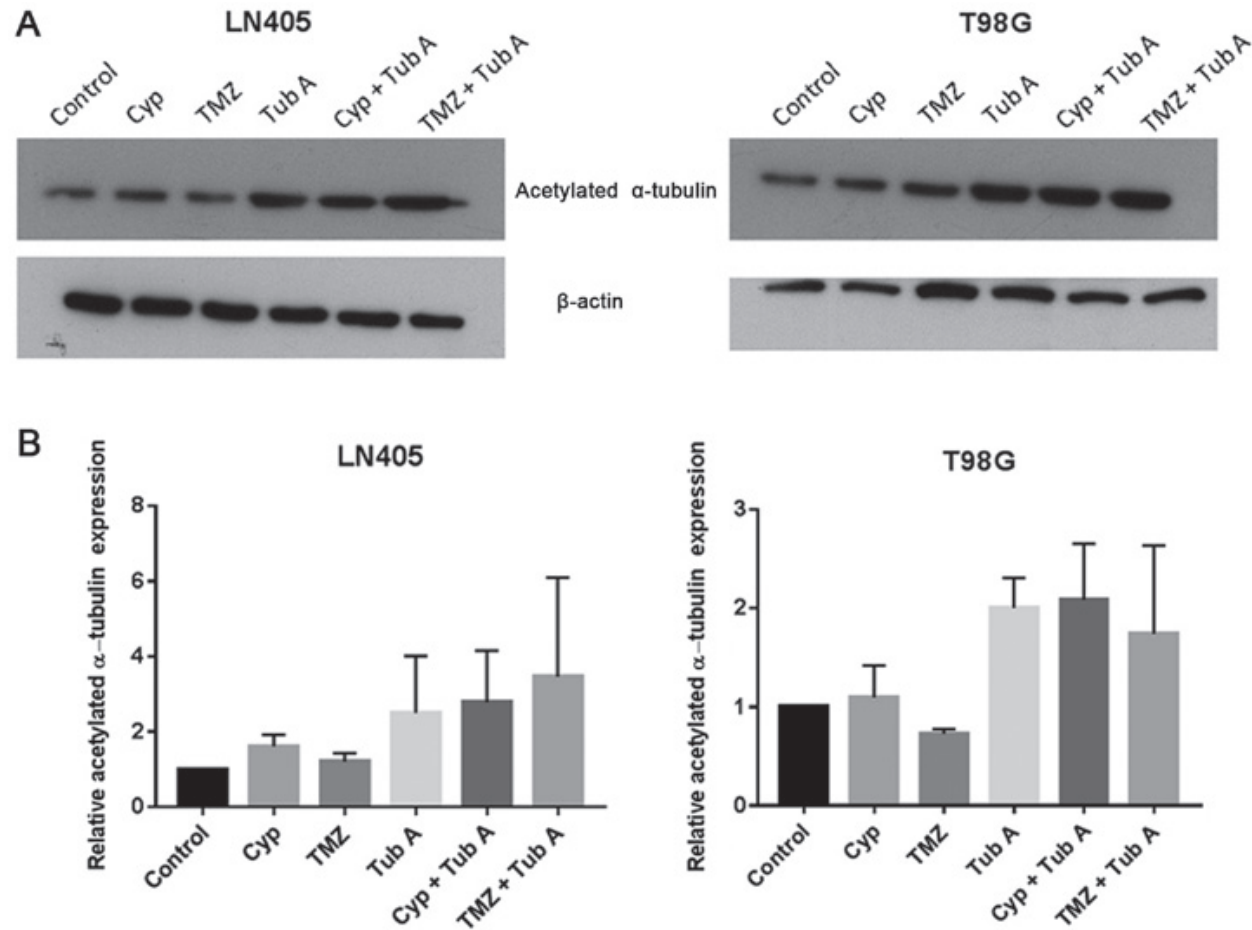

Figure 1. Expression analysis of acetylated $\alpha$-tubulin following treatments of glioblastoma cells. (A) Western blot analysis results for acetylated $\alpha$-tubulin in glioblastoma cells. TubA (alone and together with Cyp or TMZ) increased levels of acetylated $\alpha$-tubulin. (B) Relative acetylated $\alpha$-tubulin expression in glioblastoma cells (densitometric analysis of A). TubA, tubastatin A; Cyp, cyclopamine; TMZ, temozolomide.

using the comparative Cq method (33), also known as the $2^{-\Delta \Delta C q}$ method.

Protein extraction. Cells were treated at $37^{\circ} \mathrm{C}$ for $72 \mathrm{~h}$ as follows: LN405 with $27.5 \mu \mathrm{M}$ cyclopamine, $32.5 \mu \mathrm{M}$ tubastatin $\mathrm{A}$ and $400 \mu \mathrm{M}$ temozolomide; and $\mathrm{T} 98 \mathrm{G}$ with $20 \mu \mathrm{M}$ cyclopamine, $30 \mu \mathrm{M}$ tubastatin $\mathrm{A}$ and $400 \mu \mathrm{M}$ temozolomide. Concentrations and durations for the combination of cyclopamine and tubastatin $\mathrm{A}$, and the combination of temozolomide and tubastatin $\mathrm{A}$, were as for the single treatments. Additionally, 1\% DMSO was used as a vehicle control. Total protein extraction was then conducted using radio immunoprecipitation assay lysis buffer $(50 \mathrm{mM}$ Tris-hidroximetil-aminometano- $\mathrm{HCl}, \mathrm{pH} 8.0,150 \mathrm{mM} \mathrm{NaCl}$, $0.5 \%$ Triton $^{\circledR} \mathrm{X}-100$ and $0.5 \%$ sodium deoxycholate).

Western blot analysis. A total of $20 \mu \mathrm{g}$ of each bicinchoninic acid-quantified protein sample were separated in $12 \%$ SDS-PAGE and then transferred to a nitrocellulose membrane. Following blocking with TBS-Tween $0.1 \%$ and $5 \%$ non-fat milk for $1 \mathrm{~h}$ at room temperature, membranes were incubated overnight with the primary antibody at $4^{\circ} \mathrm{C}$. After three washes with TBS-Tween $0.1 \%$, membranes were incubated with the corresponding secondary antibodies at room temperature for $1 \mathrm{~h}$. To visualize the presence and quantity of protein, Lumi-LightPLUS Western blotting substrate (Merck KGaA) was used. The primary antibodies used in the present study were: Acetylated $\alpha$-tubulin (cat. no. T6793; 1:10,000; Merck KGaA) and $\beta$-actin (cat. no. A5441; 1:10,000; Merck KGaA). The secondary antibody used was horseradish peroxidase-conjugated anti-mouse (cat. no. SC-516102; 1:10,000; Santa Cruz Biotechnology, Inc., Dallas, TX, USA).
Statistical analysis. Values are expressed as the mean \pm standard deviation or as the mean \pm standard error of the mean. GraphPad 7.0 Software (GraphPad Software, Inc., La Jolla, CA, USA) was used to analyze the statistics of the results obtained from the experiments. The statistical tests used were the one-way analysis of variance and Tukey's multiple comparison test. $\mathrm{P}<0.05$ was considered to indicate a statistically significant difference.

\section{Results}

Tubastatin A increases acetylated $\alpha$-tubulin levels in glioblastoma cell lines. A western blot analysis for acetylated $\alpha$-tubulin was performed to ensure the effect of tubastatin A as an inhibitor of HDAC6 (Fig. 1) in glioblastoma cell lines. As expected, acetylated $\alpha$-tubulin protein levels increased in the groups treated with tubastatin A, both alone and together with cyclopamine or temozolomide, compared with the control group, confirming the indicated mechanism of action of this drug. In the samples treated with cyclopamine or temozolomide alone, no significant differences were observed.

Tubastatin A, alone and combined with temozolomide, reduces clonogenicity of glioblastoma cell lines. To evaluate the clonogenic capacity of T98G and LN405 glioblastoma cells after treatment with cyclopamine, temozolomide, tubastatin A, combination of cyclopamine with tubastatin A, combination of temozolomide with tubastatin A, and DMSO for $72 \mathrm{~h}$, two different colony formation experiments were performed: attachment-dependent (2D colonies); and attachment-independent conditions (3D colonies) (Fig. 2). 

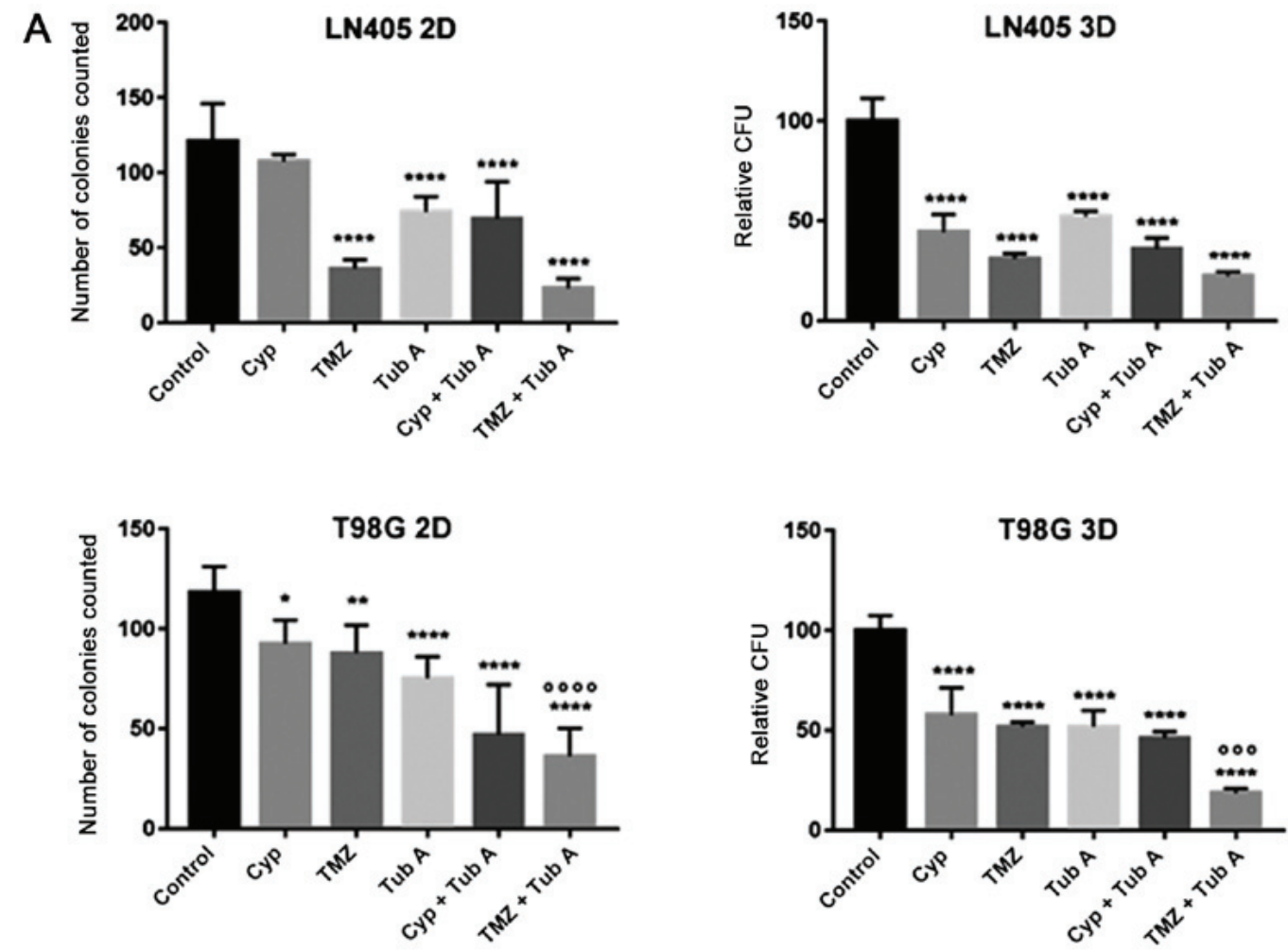

B
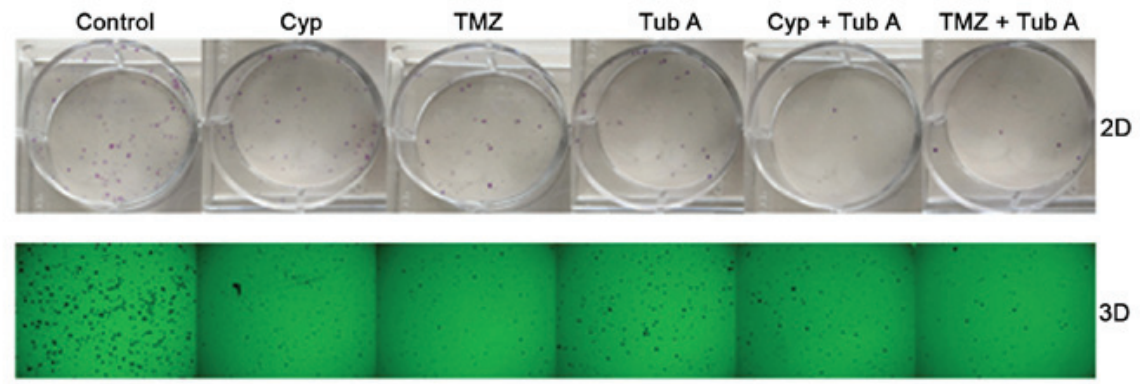

Figure 2. Changes in clonogenicity following treatments of glioblastoma cells. (A) Effect of the different treatments on the clonogenic capacity of glioblastoma cells. Data are presented as the mean \pm standard deviation. ${ }^{*} \mathrm{P}<0.05,{ }^{* * *} \mathrm{P}<0.01$, and ${ }^{* * * * *} \mathrm{P}<0.0001$, compared with control; ${ }^{\circ 00} \mathrm{P}<0.001$ and ${ }^{\circ 00} \mathrm{P}<0.0001$, compared with TMZ single treatment. (B) Representative images of 2D and 3D (soft agar) clonogenic assays in glioblastoma cells. TubA, tubastatin A; Cyp, cyclopamine; TMZ, temozolomide; CFU, colony-forming unit.

Tubastatin A single treatment, and its combination with cyclopamine and temozolomide, significantly reduced the number of colonies counted in both experiments. The combination of temozolomide with tubastatin A was the most efficient strategy for reducing clonogenicity of glioblastoma cells, compared with the untreated group or cells treated with temozolomide alone.

Tubastatin A decreases the migration capacity of glioblastoma cell lines. A wound healing or scratching assay was then conducted to analyze the migration capacity of T98G and LN405 cells following treatment with cyclopamine, temozolomide, tubastatin A, combination of cyclopamine with tubastatin A, and combination of temozolomide with tubastatin A (Fig. 3). Even if all groups exhibited a closure of the scratch after $48 \mathrm{~h}$, differences were evident among different treatments. Cyclopamine alone had no significant effect on reducing cell migration, compared with the control group. Tubastatin A induced a reduced migration rate; however, a notable inhibition was observed when both drugs were added together. The single treatment with temozolomide reduced cell migration more, compared with the individual treatment with cyclopamine. Tubastatin A produced different results in the two cell lines. When tubastatin A was combined with temozolomide, inhibition upon migration was enhanced, as demonstrated by the inability of these cells to close the gap.

Tubastatin A downregulates the sonic Hh pathway in glioblastoma cell lines. To observe whether tubastatin A treatment had any effect on the regulation of the sonic Hh pathway, in LN405 (Fig. 4) and T98G (Fig. 5) glioblastoma cell lines, total RNA was extracted from each experimental group and RT-qPCR (Table III) was performed following reverse transcription for GLI1 and Patched 1 (PTCH1) genes. Ribosomal 18S was used as a reference gene for the relative quantification of these two genes using the comparative $\mathrm{Cq}$ method. Treatment with cyclopamine had a significant effect on GLI1 and PTCH1, both significantly reducing the expression following treatment with 


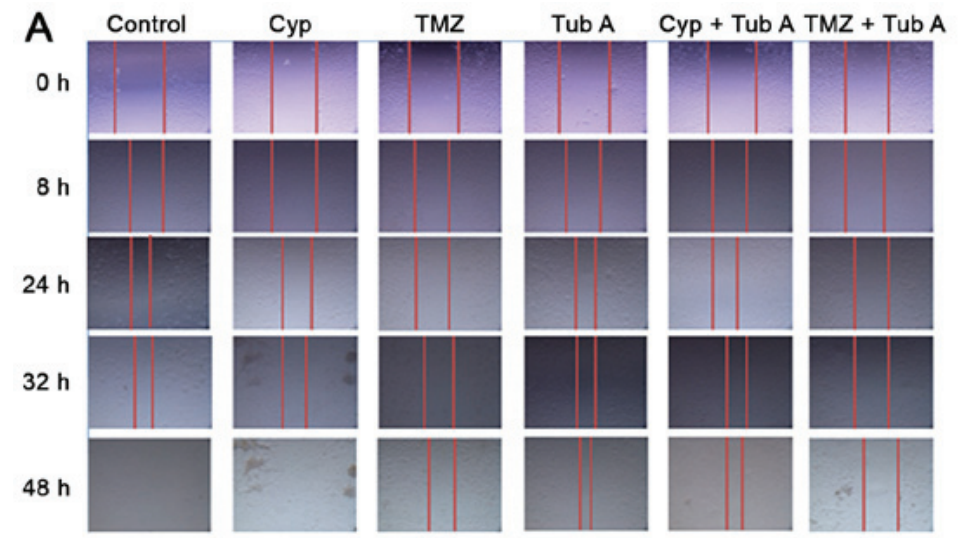

B
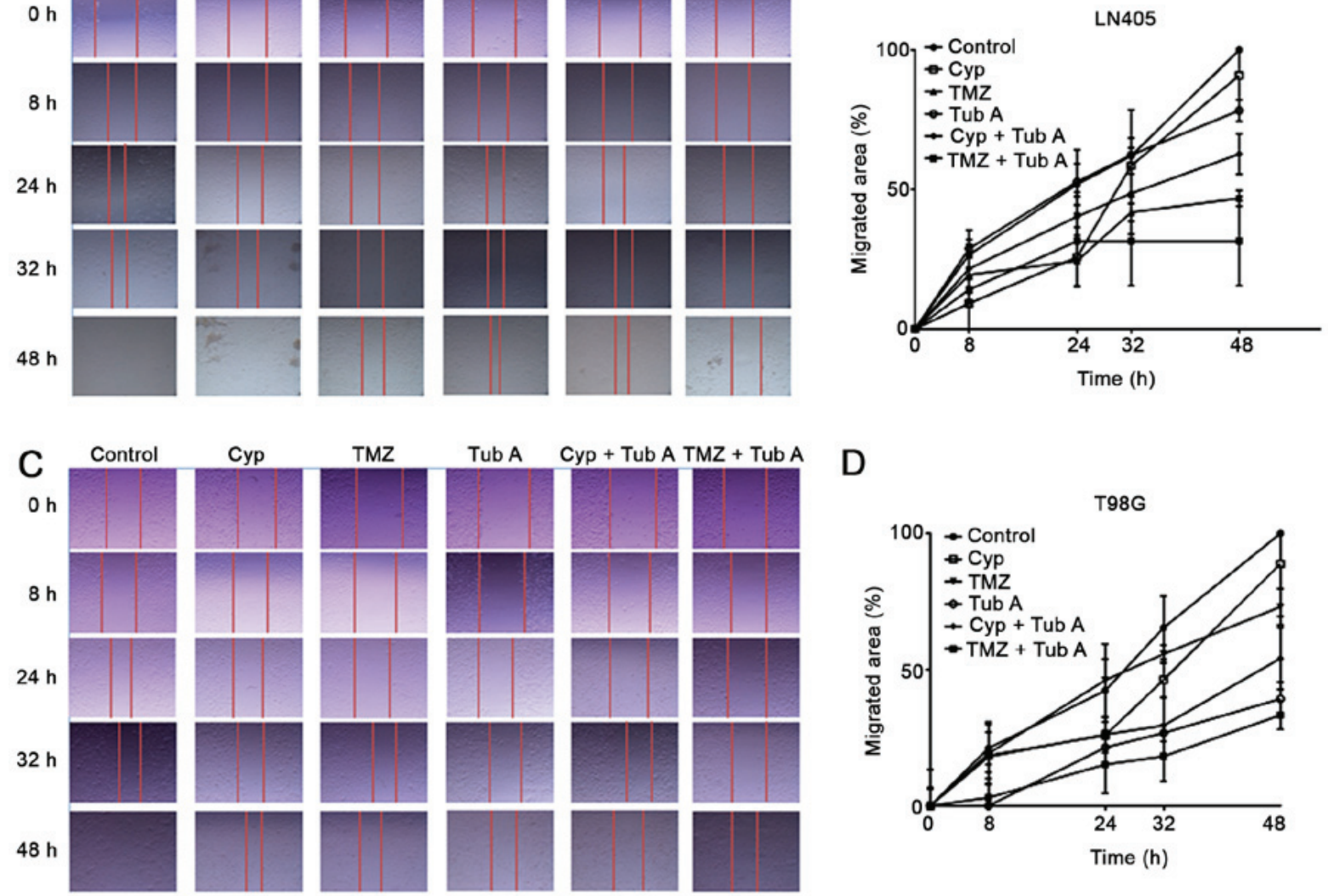

Figure 3. Changes in cell migration after treatments of glioblastoma cells. Single treatment with TubA, and combination with Cyp and TMZ, reduced cell migration with respect to Cyp or TMZ alone in glioblastoma cells. (A) LN405 cells. Images of the gap were captured at 0, 8, 24, 32 and 48 h following scratching in every treatment condition. (B) LN405 cells. Graphs representing the percentage of the migrated area in every condition are incorporated. (C) T98G cells. Images of the gap were captured at $0,8,24,32$ and $48 \mathrm{~h}$ following scratching in every treatment condition. (D) T98G cells. Graphs representing the percentage of the migrated area in every condition are incorporated. TubA, tubastatin A; Cyp, cyclopamine; TMZ, temozolomide.
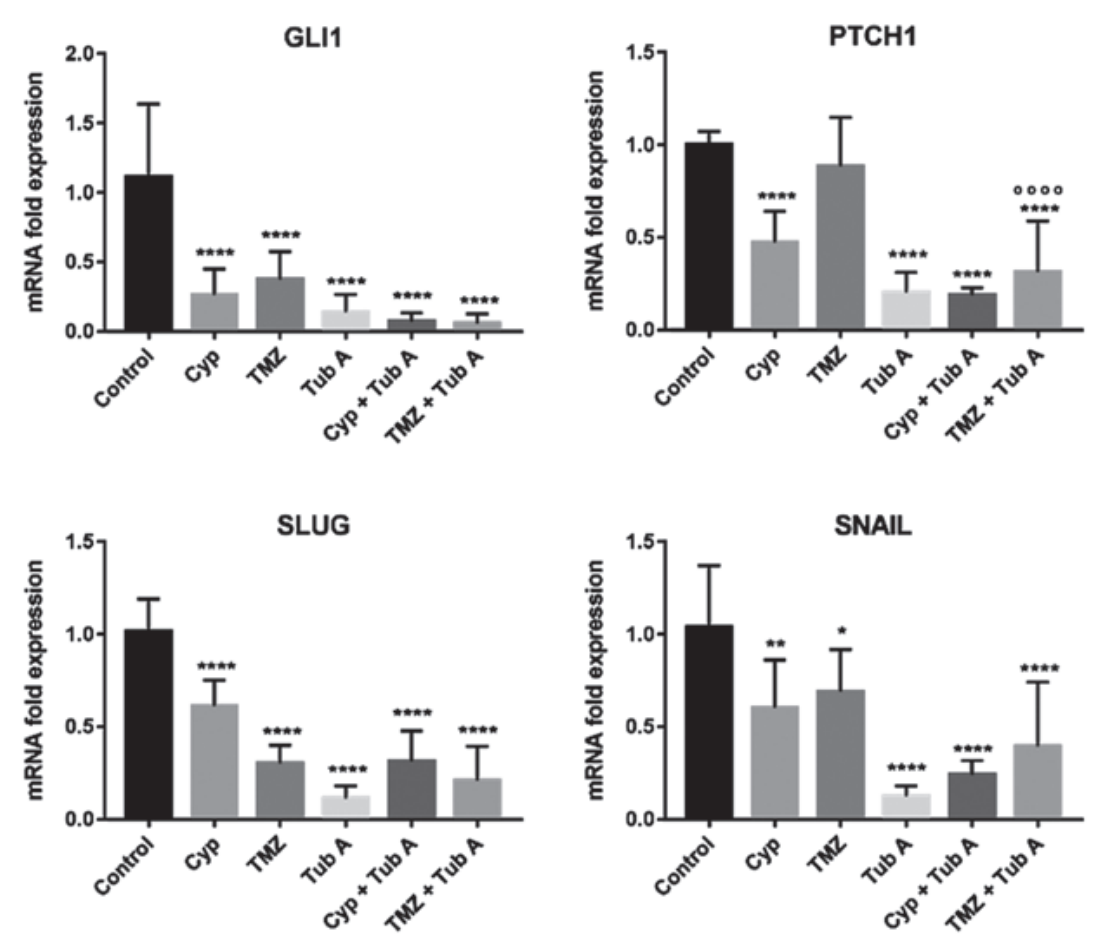

Figure 4. Changes in the expression of sonic hedgehog and EMT markers after treatments of LN405 glioblastoma cells. mRNA fold expression of sonic hedgehog markers (GLI1 and PTCH1) and EMT markers (Slug and Snail), compared with 18S in LN405 glioblastoma cells. Data are presented as the mean \pm standard deviation. ${ }^{*} \mathrm{P}<0.05,{ }^{* * *} \mathrm{P}<0.01$ and ${ }^{* * * * *} \mathrm{P}<0.0001$, compared with control; ${ }^{\text {ooso }} \mathrm{P}<0.0001$, compared with TMZ single treatment. TubA, tubastatin $\mathrm{A}$; Cyp, cyclopamine; TMZ, temozolomide; PTCH1, Patched 1; Slug, Snail family transcription repressor 2. 

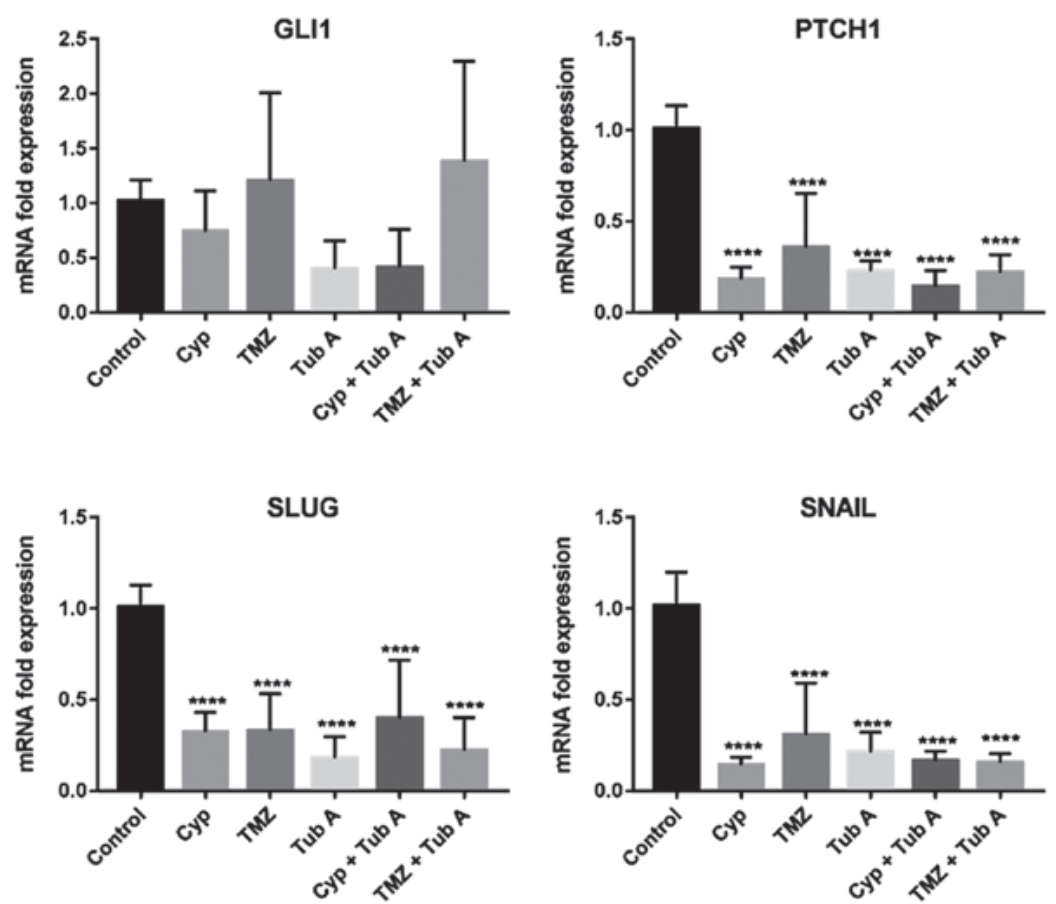

Figure 5. Changes in the expression of sonic hedgehog and EMT markers after treatments of T98G glioblastoma cells. mRNA fold expression of sonic hedgehog markers (GLI1 and PTCH1) and EMT markers (Slug and Snail), compared with 18S in T98G glioblastoma cells. Data are presented as the mean \pm standard deviation. ${ }^{* * * *} \mathrm{P}<0.0001$, compared with control. TubA, tubastatin A; Cyp, cyclopamine; TMZ, temozolomide; PTCH1, Patched 1; Slug, Snail family transcription repressor 2 .

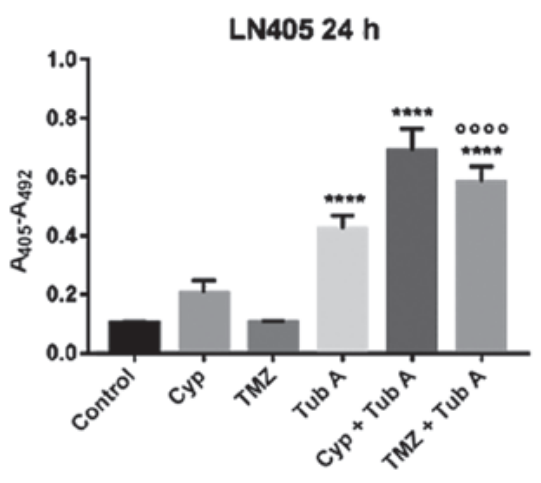

T98G 24 h

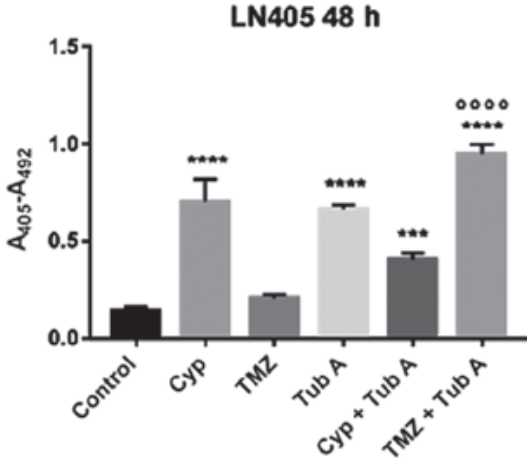

T98G $48 \mathrm{~h}$
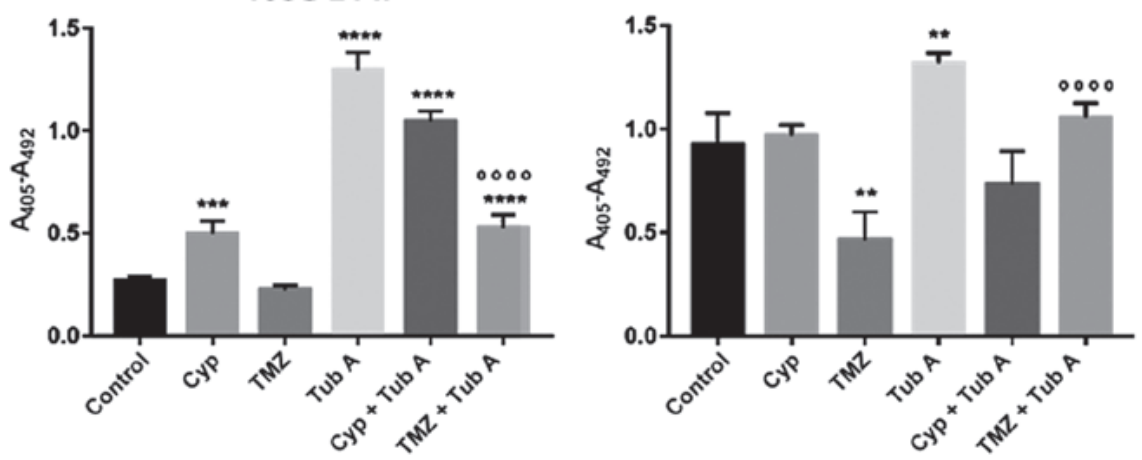

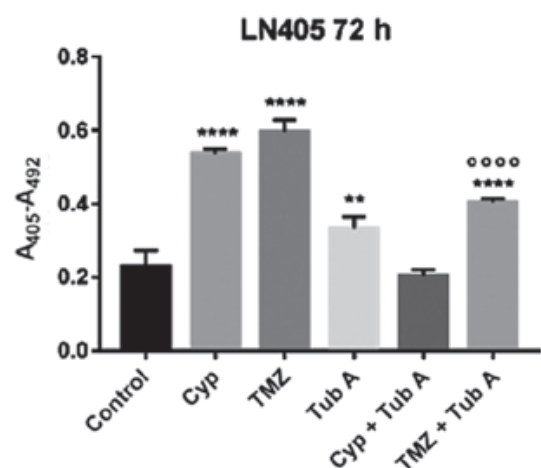

T98G $72 \mathrm{~h}$

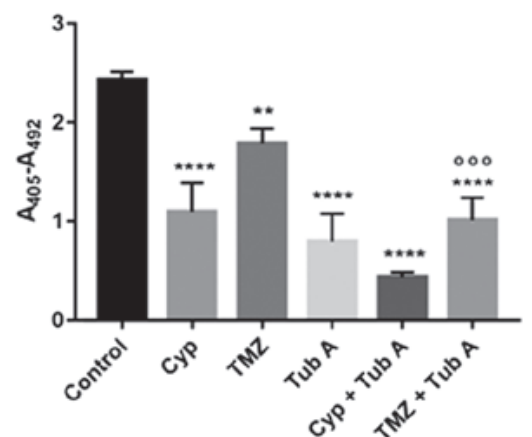

Figure 6. Changes in apoptosis, by ELISA, after treatments of LN405 and T98G glioblastoma cells. Data are presented as the mean \pm standard deviation. ${ }^{* *} \mathrm{P}<0.01,{ }^{* * *} \mathrm{P}<0.001$ and ${ }^{* * * *} \mathrm{P}<0.0001$, compared with control; ${ }^{\circ 00} \mathrm{P}<0.001$ and ${ }^{\circ 000} \mathrm{P}<0.0001$, compared with TMZ single treatment. TubA, tubastatin $\mathrm{A}$; Cyp, cyclopamine; TMZ, temozolomide.

these drugs. Nevertheless, in both cases, the most significant decrease of PTCH1 expression was observed when cells were treated both with cyclopamine and tubastatin $\mathrm{A}$, indicating that acetylation of $\alpha$-tubulin and the possible restoration of primary cilia may result in a downregulation of the sonic Hh pathway. Additionally, the combined treatment of temozolomide and 

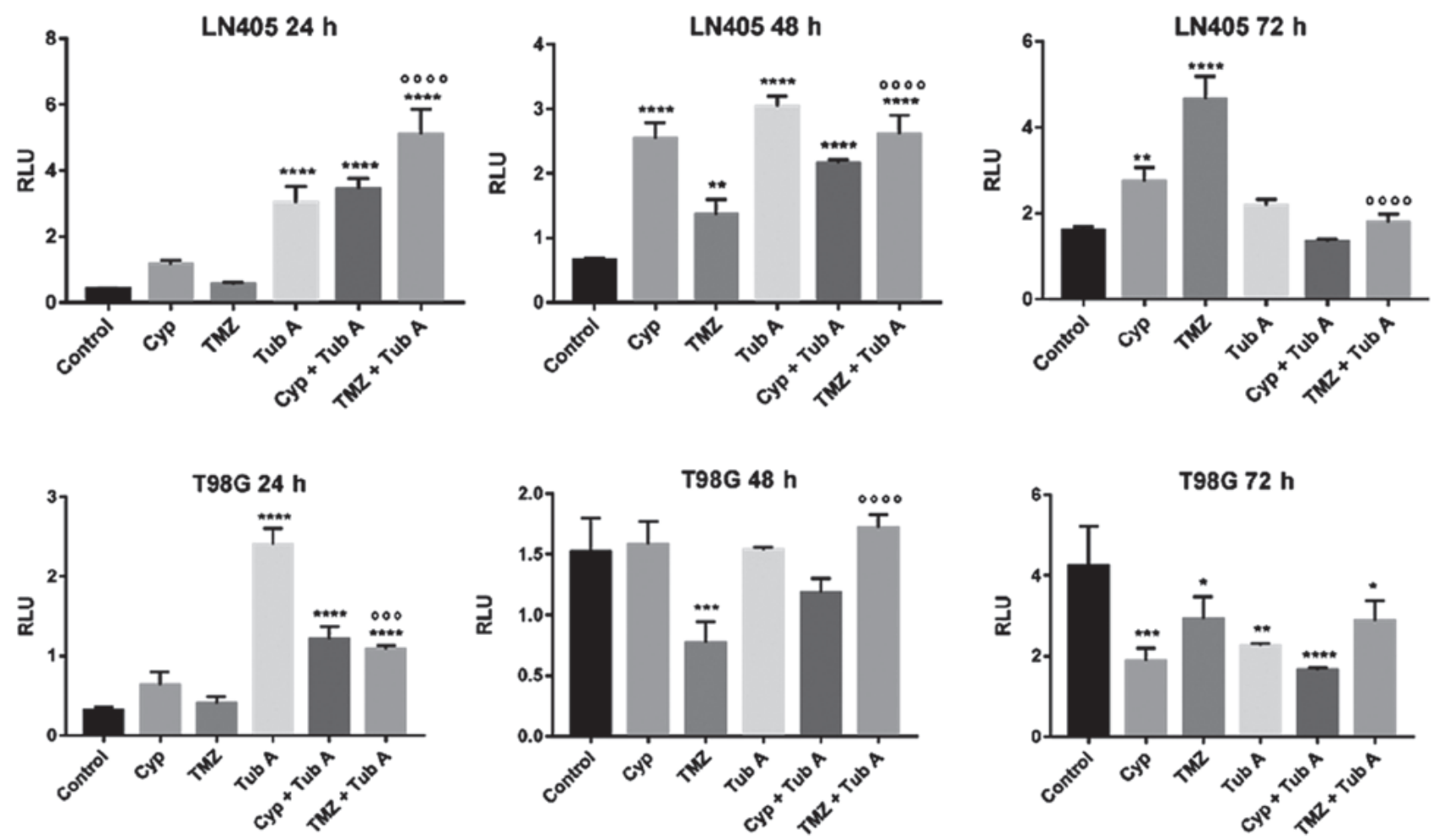

Figure 7. Changes in apoptosis, by caspase $3 / 7$ activation, after treatments of LN405 and T98G glioblastoma cells. Data are presented as the mean \pm standard deviation. ${ }^{*} \mathrm{P}<0.05,{ }^{* *} \mathrm{P}<0.01,{ }^{* * * *} \mathrm{P}<0.001$ and ${ }^{* * * *} \mathrm{P}<0.0001$, compared with control; ${ }^{\circ 00} \mathrm{P}<0.001$ and ${ }^{\circ 000} \mathrm{P}<0.0001$, compared with TMZ single treatment. TubA, tubastatin A; Cyp, cyclopamine; TMZ, temozolomide; RLU, relative light units.

tubastatin A decreased GLI and PTCH1 expression more, compared with temozolomide alone.

Tubastatin A downregulates the expression of mesenchymal markers in glioblastoma cell lines. EMT was investigated by RT-qPCR (Table III) for the mesenchymal markers Snail and Snail family transcriptional repressor 2 (Slug) in LN405 (Fig. 4) and T98G (Fig. 5) glioblastoma cell lines. The greatest reduction in expression of those markers was observed in the tubastatin A single treatment. However, when tubastatin A did not produce the greatest decay in expression of the markers, the double treatments exhibited the greatest decay.

Tubastatin A accelerates temozolomide action on apoptosis in glioblastoma cell lines. In order to investigate the effect of cyclopamine, tubastatin A and temozolomide on apoptosis in T98G and LN405 glioblastoma cells, two different experiments were performed: Cell death detection ELISAPLUS (Fig. 6); and Caspase-Glo 3/7 assay (Fig. 7). Evolution of both apoptosis processes was monitored at 24,48 and $72 \mathrm{~h}$ after treatment. Both experiments demonstrated similar results, strengthening the validation of these assays.

The treatment with cyclopamine had different effects when inducing apoptosis in the two cell lines. In LN405 cells, cyclopamine continued to induce apoptosis after $72 \mathrm{~h}$ of treatment, whereas it did not have any effect in T98G cells after $48 \mathrm{~h}$, when the values were equalized with respect to its control. The combination of cyclopamine with tubastatin A increased apoptosis at $24 \mathrm{~h}$ in both cell lines more than cyclopamine alone.

Tubastatin A notably induced apoptosis at 24 and $48 \mathrm{~h}$ with respect to the control, but this induction was attenuated after reaching $72 \mathrm{~h}$. The combination of tubastatin A with temozolomide improved the increase of apoptosis induced by temozolomide alone, at 24 and $48 \mathrm{~h}$. However, at $72 \mathrm{~h}$, temozolomide alone produced the greatest increase in apoptosis, indicating that the combination with tubastatin A accelerates the action of temozolomide on apoptosis.

\section{Discussion}

Glioblastoma is the most common and the most malignant form of brain tumor (1). Despite the therapeutic effort conducted to treat this type of glioma, the majority of patients develop resistance and have a poor prognosis $(2,34)$. The aim of the present study was to investigate the effect of tubastatin A, a selective HDAC6 inhibitor, on glioblastoma cell lines. The cells used in the present study, which lack the primary cilium (14), may restore it under treatment with tubastatin A, and consequently, the cells may also reverse their malignant phenotype and become sensitive to chemotherapy. The present results demonstrated statistical differences encountered following treating the glioblastoma cell lines with cyclopamine, temozolomide, tubastatin A, combination of cyclopamine and tubastatin A, combination of temozolomide with tubastatin A, or DMSO, as a vehicle control.

With western blot analysis, an increase in acetylated $\alpha$-tubulin levels following treatment with tubastatin A, alone or combined with cyclopamine or temozolomide, was demonstrated (Fig. 1). This result was expected, as inhibition of HDAC6 inhibits $\alpha$-tubulin deacetylation $(15,35)$. The increase in acetylated $\alpha$-tubulin was greater when tubastatin A and temozolomide was used in the LN405 cell line, while this 
increase with the combination treatment was not observed in the T98G cell line. Therefore, it should be considered that LN405 and T98G may produce different results, as although they are glioblastoma cell lines, they are different at the molecular level, as LN405 cells exhibit mutations in TP53 and phosphatase and tensin homolog (PTEN), while T98G cell exhibit mutations in TP53, but not in PTEN.

Both in vitro cell tumorigenicity experiments, the 2D colony formation assay and the 3D soft agar colony formation assay (Fig. 2), revealed a significant decrease in clonogenicity of glioblastoma cell lines following inhibition of HDAC6. A similar effect was observed when tubastatin A was combined with cyclopamine in the 3D assay. However, the combined therapy with temozolomide was the most efficient treatment when it comes to reducing tumor growth, as determined by the number of colonies counted. This indicates that HDAC6 inhibition successfully reduces glioblastoma cell growth, as occurs in other tumor types, including cholangiocarcinoma (36), and may sensitize them to chemotherapy with temozolomide.

This observation was reinforced following analyzing the results for the cell migration test in the wound healing assay (Fig. 3). As occurs in the colony formation assays, single treatment with cyclopamine or temozolomide did not produce any significant difference, compared with the control group. However, when tubastatin A was added, alone or combined with any of the two other drugs, a significant inhibition of the cell migration capacity was observed, which indicates tubastatin $\mathrm{A}$ as a potential adjuvant drug to be administered together with temozolomide.

Modulation of the sonic Hh pathway by tubastatin A was also investigated. As depicted in Figs. 4 and 5, tubastatin A was the only drug that achieved a decrease in the mRNA levels of GLI1 and PTCH1, and therefore a downregulation of the sonic Hh pathway, when administered alone. However, in the present study, a greater decrease was expected when tubastatin A was combined with cyclopamine, as restoration of the primary cilium caused by tubastatin A would allow the action of cyclopamine on Smo inhibition. This combined treatment also reduced GLI1 expression, compared with untreated cells. These results may confirm the role of the primary cilium in sonic $\mathrm{Hh}$ regulation and the efficiency of the cyclopamine and tubastatin A treatment in modulating the pathway when disrupted.

Finally, regarding the two genes associated with EMT, the RT-qPCR experiments demonstrated a notable decrease in expression of the mesenchymal genes Snail and Slug in all treated groups, compared with the control group, even though these differences were not statistically significant (Figs. 4 and 5). These observations indicated a reversion of the EMT transition in these cells, as these markers belong to a mesenchymal phenotype $(37,38)$. However, a report published by Stepanenko et al (39) demonstrated that a number of glioblastoma cell lines treated with temozolomide increase vimentin and Slug levels, although it was not the case for T98G cells. Additionally, it was documented (40) that the loss of $\alpha$-tubulin acetylation acts as a mesenchymal marker for EMT; therefore, increased expression of HDAC6 induces EMT. It can be considered that treatment with tubastatin A is not only inducing the reversion of EMT to a MET phenotype in glioblastoma cells, as it has been demonstrated to increase acetylated $\alpha$-tubulin levels, but also represses TGF-1 induced EMT in cultured peritoneal mesothelial cells, preventing peritoneal fibrosis (30).

In the apoptosis assays (Fig. 6 and 7), cyclopamine increased cell death during the first $24 \mathrm{~h}$ after treatment, but cannot be considered an efficient drug when it comes to inducing apoptosis. Additionally, the cyclopamine and tubastatin A combination treatment for $24 \mathrm{~h}$ produced an increased effect, compared with cyclopamine alone. Simultaneously, temozolomide single treatment did not produce increased apoptosis, compared with the untreated group, which is a poor result. Nevertheless, the most notable result from this experiment is the highlighted effect of the inhibition of HDAC6 on inducing apoptosis. Tubastatin A has been demonstrated to promote cell death at a high rate not only in glioblastoma cells, but also in other tumor types, including gastric cancer (41). Additionally, tubastatin A accelerates temozolomide action, as the effect of single treatment with temozolomide was already achieved $24 \mathrm{~h}$ earlier with the combined treatment. This may be due to the fact that the inhibition of HDAC6 favors the sensitization of the cells to temozolomide, since tumors with overexpression of HDAC6 have an increased resistance to temozolomide (42). Furthermore, a novel mechanism for a possible explanation of the increase of apoptosis by HDAC6 inhibition has recently been determined (43), demonstrating that HDAC6-selective inhibition is a novel epigenetic anticancer therapeutic strategy targeting the p53-Hsp90 complex that can be applied to wild-type p53-and mutated p53-bearing cancer, with similar efficacy.

The present results indicated that the primary cilium acts as a tumor suppressor in these glioblastoma cells, as well as in other glioblastoma cell lines, including U87-MG, U-373G, U-138MG or U-251MG (44), and other tumor types, including cholangiocarcinoma (36), breast cancer (45), melanoma (46), sporadic clear cell renal cell carcinoma (47), prostate cancer (48) and lung cancer (49). However, there are studies that indicate that cilia may function as an oncogene in other cases, including pancreatic ductal carcinoma (50) and medulloblastoma (51), and other different glioblastoma cell lines, due to the complicated heterogeneity of glioblastoma attributed to the different responses of different cell lines or patients (52). For this reason, characterization of the patients is notable in order to classify them as cilia positive or cilia negative, prior to choosing which therapeutic strategy fits them best. However, a number of other cellular tests and molecular experiments with more markers are required with different glioblastoma cell lines prior to determine the result, as the observations up to now are preliminary.

\section{Acknowledgements}

Not applicable.

\section{Funding}

Financial support for this work was provided by a grant from the Fundación Universidad de Navarra (Pamplona, Spain). AU has been granted a predoctoral fellowship from the Asociación de Amigos de la Universidad de Navarra (Pamplona, Spain). 


\section{Availability of data and materials}

All data generated or analyzed during this study are included within the manuscript.

\section{Authors' contributions}

AU, EE, BM, JAR, MAI and JSC conceived and designed the experiments. AU and EE performed the experiments. AU, EE and JSC analyzed the data. EE and JSC drafted the paper. All authors contributed to refine analysis of data and writing of the manuscript. All authors read and approved the final manuscript.

\section{Ethics approval and consent to participate}

Not applicable.

\section{Patient consent for publication}

Not applicable.

\section{Competing interests}

The authors declare that they have no competing interests.

\section{References}

1. Jovčevska I, Kočevar N and Komel R: Glioma and glioblastoma - how much do we (not) know? Mol Clin Oncol 1: 935-941, 2013.

2. Bleeker FE, Molenaar RJ and Leenstra S: Recent advances in the molecular understanding of glioblastoma. J Neurooncol 108: 11-27, 2012.

3. Thomas A, Tanaka M, Trepel J, Reinhold WC, Rajapakse VN and Pommier Y: Temozolomide in the era of precision medicine. Cancer Res 77: 823-826, 2017.

4. Perry J, Laperriere N, Zuraw L, Chambers A, Spithoff K and Cairncross JG; Neuro-oncology Disease Site Group; Cancer Care Ontario Program in Evidence-Based Care: Adjuvant chemotherapy for adults with malignant glioma: A systematic review. Can J Neurol Sci 34: 402-410, 2007.

5. Stupp R, Mason WP, van den Bent MJ, Weller M, Fisher B, Taphoorn MJ, Belanger $\mathrm{K}$, Brandes AA, Marosi C, Bogdahn U, et al; European Organisation for Research and Treatment of Cancer Brain Tumor and Radiotherapy Groups; National Cancer Institute of Canada Clinical Trials Group: Radiotherapy plus concomitant and adjuvant temozolomide for glioblastoma. N Engl J Med 352: 987-996, 2005.

6. Kitange GJ, Carlson BL, Schroeder MA, Grogan PT, Lamont JD, Decker PA, Wu W, James CD and Sarkaria JN: Induction of MGMT expression is associated with temozolomide resistance in glioblastoma xenografts. Neuro-oncol 11: 281-291, 2009.

7. Qiu ZK, Shen D, Chen YS, Yang QY, Guo CC, Feng BH and Chen ZP: Enhanced MGMT expression contributes to temozolomide resistance in glioma stem-like cells. Chin J Cancer 33: 115-122, 2014

8. Hegi ME, Diserens AC, Gorlia T, Hamou MF, de Tribolet N, Weller M, Kros JM, Hainfellner JA, Mason W, Mariani L, et al: MGMT gene silencing and benefit from temozolomide in glioblastoma. N Engl J Med 352: 997-1003, 2005.

9. Kondo N, Takahashi A, Ono K and Ohnishi T: DNA damage induced by alkylating agents and repair pathways. J Nucleic Acids 2010: 543531, 2010.

10. Aldana-Masangkay GI and Sakamoto KM: The role of HDAC6 in cancer. J Biomed Biotechnol 2011: 875824, 2011.

11. Seidel C, Schnekenburger M, Dicato M and Diederich M: Histone deacetylase 6 in health and disease. Epigenomics 7: 103-118, 2015

12. Smith Q, Macklin B, Chan XY, Jones H, Trempel M, Yoder MC and Gerecht S: Differential HDAC6 activity modulates ciliogenesis and subsequent mechanosensing of endothelial cells derived from pluripotent stem cells. Cell Rep 24: 895-908.e6, 2018
13. Li S, Liu X, Chen X, Zhang L and Wang X: Histone deacetylase 6 promotes growth of glioblastoma through inhibition of SMAD2 signaling. Tumour Biol 36: 9661-9665, 2015.

14. Moser JJ, Fritzler MJ and Rattner JB: Primary ciliogenesis defects are associated with human astrocytoma/glioblastoma cells. BMC Cancer 9: 448, 2009.

15. Wang Z, Hu P, Tang F, Lian H, Chen X, Zhang Y, He X, Liu W and Xie C: HDAC6 promotes cell proliferation and confers resistance to temozolomide in glioblastoma. Cancer Lett 379: 134-142, 2016.

16. Corbit KC, Aanstad P, Singla V, Norman AR, Stainier DY and Reiter JF: Vertebrate Smoothened functions at the primary cilium. Nature 437: 1018-1021, 2005.

17. Haycraft CJ, Banizs B, Aydin-Son Y, Zhang Q, Michaud EJ and Yoder BK: Gli2 and Gli3 localize to cilia and require the intraflagellar transport protein polaris for processing and function. PLoS Genet 1: e53, 2005.

18. Simons M, Gloy J, Ganner A, Bullerkotte A, Bashkurov M, Krönig C, Schermer B, Benzing T, Cabello OA, Jenny A, et al: Inversin, the gene product mutated in nephronophthisis type II, functions as a molecular switch between Wnt signaling pathways. Nat Genet 37: 537-543, 2005.

19. Goetz SC and Anderson KV: The primary cilium: A signalling centre during vertebrate development. Nat Rev Genet 11:331-344, 2010.

20. Braun S, Oppermann H, Mueller A, Renner C, Hovhannisyan A, Baran-Schmidt R, Gebhardt R, Hipkiss A, Thiery J, Meixensberger $\mathrm{J}$, et al: Hedgehog signaling in glioblastoma multiforme. Cancer Biol Ther 13: 487-495, 2012.

21. Hassounah NB, Bunch TA and McDermott KM: Molecular pathways: The role of primary cilia in cancer progression and therapeutics with a focus on Hedgehog signaling. Clin Cancer Res 18: 2429-2435, 2012.

22. Pasca di Magliano M and Hebrok M: Hedgehog signalling in cancer formation and maintenance. Nat Rev Cancer 3: 903-911, 2003.

23. Liu YJ, Ma YC, Zhang WJ, Yang ZZ, Liang DS, Wu ZF and Qi XR: Combination therapy with micellarized cyclopamine and temozolomide attenuate glioblastoma growth through Gli1 down-regulation. Oncotarget 8: 42495-42509, 2017.

24. Kalluri R and Weinberg RA: The basics of epithelial-mesenchymal transition. J Clin Invest 119: 1420-1428, 2009.

25. Skrypek N, Goossens S, De Smedt E, Vandamme N and Berx G: Epithelial-to-mesenchymal transition: Epigenetic reprogramming driving cellular plasticity. Trends Genet 33: 943-959, 2017.

26. Zeisberg M and Neilson EG: Biomarkers for epithelial-mesenchymal transitions. J Clin Invest 119: 1429-1437, 2009.

27. Ramos FS, Wons L, Cavalli IJ and Ribeiro EMSF: Epithelial-mesenchymal transition in cancer: An overview. Integr Cancer Sci Ther 4: 1-5, 2017.

28. Iwadate Y: Epithelial-mesenchymal transition in glioblastoma progression. Oncol Lett 11: 1615-1620, 2016.

29. Kahlert UD, Maciaczyk D, Doostkam S, Orr BA, Simons B, Bogiel T, Reithmeier T, Prinz M, Schubert J, Niedermann G, et al: Activation of canonical WNT/ $\beta$-catenin signaling enhances in vitro motility of glioblastoma cells by activation of ZEB1 and other activators of epithelial-to-mesenchymal transition. Cancer Lett 325: 42-53, 2012.

30. Xu L, Liu N, Gu H, Wang H, Shi Y, Ma X, Ma S, Ni J, Tao M, Qiu A, et al: Histone deacetylase 6 inhibition counteracts the epithelial-mesenchymal transition of peritoneal mesothelial cells and prevents peritoneal fibrosis. Oncotarget 8: 88730-88750, 2017.

31. Dunigan DD, Waters SB and Owen TC: Aqueous soluble tetrazolium/formazan MTS as an indicator of NADH- and NADPH-dependent dehydrogenase activity. Biotechniques 19: 640-649, 1995 .

32. Geissmann Q: OpenCFU, a new free and open-source software to count cell colonies and other circular objects. PLoS One 8: e54072, 2013

33. Schmittgen TD and Livak KJ: Analyzing real-time PCR data by the comparative C(T) method. Nat Protoc 3: 1101-1108, 2008

34. Urdiciain A, Meléndez B, Rey JA, Idoate MA and Castresana JS: Panobinostat potentiates temozolomide effects and reverses epithelial-mesenchymal transition in glioblastoma cells. Epigenomes 2: 5, 2018.

35. Yang W, Liu Y, Gao R, Yu H and Sun T: HDAC6 inhibition induces glioma stem cells differentiation and enhances cellular radiation sensitivity through the $\mathrm{SHH} / \mathrm{Glil}$ signaling pathway. Cancer Lett 415: 164-176, 2018. 
36. Gradilone SA, Radtke BN, Bogert PS, Huang BQ, Gajdos GB and LaRusso NF: HDAC6 inhibition restores ciliary expression and decreases tumor growth. Cancer Res 73: 2259-2270, 2013

37. Han SP, Kim JH, Han ME, Sim HE, Kim KS, Yoon S, Baek SY, Kim BS and Oh SO: SNAI1 is involved in the proliferation and migration of glioblastoma cells. Cell Mol Neurobiol 31: 489-496, 2011.

38. Myung JK, Choi SA, Kim SK, Wang KC and Park SH: Snail plays an oncogenic role in glioblastoma by promoting epithelial mesenchymal transition. Int J Clin Exp Pathol 7: 1977-1987, 2014

39. Stepanenko AA, Andreieva SV, Korets KV, Mykytenko DO, Baklaushev VP, Huleyuk NL, Kovalova OA, Kotsarenko KV, Chekhonin VP, Vassetzky YS, et al: Temozolomide promotes genomic and phenotypic changes in glioblastoma cells. Cancer Cell Int 16: 36, 2016.

40. Gu S, Liu Y, Zhu B, Ding K, Yao TP, Chen F, Zhan L, Xu P, Ehrlich M, Liang T, et al: Loss of $\alpha$-tubulin acetylation is associated with TGF- $\beta$-induced epithelial-mesenchymal transition. J Biol Chem 291: 5396-5405, 2016.

41. Dong J, Zheng N, Wang X, Tang C, Yan P, Zhou HB and Huang J: A novel HDAC6 inhibitor exerts an anti-cancer effect by triggering cell cycle arrest and apoptosis in gastric cancer. Eur J Pharmacol 828: 67-79, 2018.

42. Li ZY, Zhang C, Zhang Y, Chen L, Chen BD, Li QZ, Zhang XJ and Li WP: A novel HDAC6 inhibitor Tubastatin A: Controls HDAC6-p97/VCP-mediated ubiquitination-autophagy turnover and reverses Temozolomide-induced ER stress-tolerance in GBM cells. Cancer Lett 391: 89-99, 2017.

43. Ryu HW, Shin DH, Lee DH, Choi J, Han G, Lee KY and Kwon SH: HDAC6 deacetylates p53 at lysines 381/382 and differentially coordinates p53-induced apoptosis. Cancer Lett 391: 162-171, 2017.

44. Sarkisian MR, Siebzehnrubl D, Hoang-Minh L, Deleyrolle L, Silver DJ, Siebzehnrubl FA, Guadiana SM, Srivinasan G, Semple-Rowland S, Harrison JK, et al: Detection of primary cilia in human glioblastoma. J Neurooncol 117: 15-24, 2014.
45. Menzl I, Lebeau L, Pandey R, Hassounah NB, Li FW, Nagle R, Weihs K and McDermott KM: Loss of primary cilia occurs early in breast cancer development. Cilia 3: 7, 2014.

46. Kim J, Dabiri S and Seeley ES: Primary cilium depletion typifies cutaneous melanoma in situ and malignant melanoma. PLoS One 6: e27410, 2011.

47. Schraml P, Frew IJ, Thoma CR, Boysen G, Struckmann K, Krek W and Moch H: Sporadic clear cell renal cell carcinoma but not the papillary type is characterized by severely reduced frequency of primary cilia. Mod Pathol 22: 31-36, 2009.

48. Liu Z, Rebowe RE, Wang Z, Li Y, Wang Z, DePaolo JS, Guo J, Qian C and Liu W: KIF3a promotes proliferation and invasion via Wnt signaling in advanced prostate cancer. Mol Cancer Res 12: 491-503, 2014

49. Kim M, Suh YA, Oh JH, Lee BR, Kim J and Jang SJ: KIF3A binds to $\beta$-arrestin for suppressing $\mathrm{Wnt} / \beta$-catenin signalling independently of primary cilia in lung cancer. Sci Rep 6: 32770 , 2016.

50. Emoto K, Masugi Y, Yamazaki K, Effendi K, Tsujikawa H, Tanabe M, Kitagawa Y and Sakamoto M: Presence of primary cilia in cancer cells correlates with prognosis of pancreatic ductal adenocarcinoma. Hum Pathol 45: 817-825, 2014.

51. Barakat MT, Humke EW and Scott MP: Kif3a is necessary for initiation and maintenance of medulloblastoma. Carcinogenesis 34: 1382-1392, 2013.

52. Lai SW, Huang BR, Liu YS, Lin HY, Chen CC, Tsai CF, Lu DY and Lin C: Differential characterization of temozolomide-resistant human glioma cells. Int J Mol Sci 19: 127, 2018. 